\title{
Service innovation in Indian knowledge-intensive business services: the Wipro case
}

\section{Andrea Appolloni*, Muge Mavisu and Sunil Kumar Tarangapade}

Department of Business, Government, Philosophy Studies, University of Rome 'Tor Vergata',

Via Columbia 2, 00133 Rome, Italy

Fax: +39-06-72595804

E-mail: andrea.appolloni@uniroma2.it

E-mail: mugemavisu@gmail.com

E-mail: tarangapade@gmail.com

*Corresponding author

\begin{abstract}
Innovation is a major factor in the survival of many firms; more specifically for firms in the service sector. Since the service industry is growing fast in India, knowledge intensive business services (KIBS) have understood the need for innovation through the creation and distribution of knowledge. Current literature on service innovation has rarely examined the internal innovation of KIBS firms; it has only been focusing on the acting role of KIBS in innovation for their client firms. Information transfer, design, and implementation of knowledge to the client firm are services provided by KIBS. Helping in to understand the relationships between knowledge management and innovation in KIBS provides ample scope for empirical investigation. The aim of the research is to extend Nonaka and Takeuchi's (1995) knowledge management life cycle model and to prove, internal and external knowledge acts as a tool for service innovation, in Indian KIBS. Through a case study on a leading Indian KIBS - Wipro - we try to complement existing theory on service innovation with specific reference to knowledge management in KIBS.
\end{abstract}

Keywords: knowledge intensive business services; KIBS; knowledge intensive business firms; innovation; services; internal knowledge; external knowledge; knowledge management.

Reference to this paper should be made as follows: Appolloni, A., Mavisu, M. and Tarangapade, S.K. (2013) 'Service innovation in Indian knowledge-intensive business services: the Wipro case', Int. J. Learning and Intellectual Capital, Vol. 10, Nos. 3/4, pp.276-293.

Biographical notes: Andrea Appolloni is an Assistant Professor in Management at Department of Business Government Philosophy Studies, University of Rome Tor Vergata, Italy. His research interests mainly lie in the fields of procurement, supply chain management, sustainability, international management and management consulting.

Muge Mavisu is a $\mathrm{PhD}$ student in Management at Department of Business Government Philosophy Studies, University of Rome-Tor Vergata, Italy. Her research interests mainly lie in the field of international management, knowledge management, management consulting, human resource management and total quality management. 


\begin{abstract}
Sunil Kumar Tarangapade is a $\mathrm{PhD}$ student in Management at Department of Business Government Philosophy Studies, University of Rome-Tor Vergata, Italy. His research interests mainly lie in the fields of corporate social responsibility and human resource management.

This paper is a revised and expanded version of a paper entitled 'Service innovation in Indian knowledge-intensive business services' presented at the Social Innovation for Competitiveness, Organizational Performance and Human Excellence, Rotterdam School of Management, Erasmus University, Rotterdam Holland, 6-8 June 2012.
\end{abstract}

\title{
1 Introduction
}

In the current scenario most organisations have started to depend on services for market growth, profits and sustainability. The ferocity of competition and rapid change in technology indicates that innovation is an important factor for competitive advantage for service firms (Martin and Horne, 1993). Innovation is an outcome of new technologies, substantive investments and the acquisition of new knowledge (Eurostat, 1995).

In developed countries, knowledge intensive business service (KIBS) are the main components of the services sector (Strambach, 2001). KIBS are practitioners and advisers of innovation business (Kelley with Littman, 2001). Information transfer, design and implementation of knowledge to the client firm are services provided by KIBS; helping in understanding the relationships between knowledge management and innovation, KIBS provide ample scope for empirical context (Miles et al., 1995). Current literatures on service innovation have rarely examined the internal innovation of Indian KIBS firms (Hauknes, 1998; den Hertog, 2000).

KIBS firms improve the capability of innovation in client firms through a flow of knowledge thereby causing a response for their own innovation (Muller and Zenker, 2001). Acquiring external knowledge through external sources because of its distinctiveness is very important for KIBS and helps in enhancing innovation by integrating acquired knowledge with existing knowledge (Ahuja and Katila, 2001; Child et al., 2001; Haspeslagh and Jemison, 1991). KIBS should know ways for integration, processing a combination of external and internal knowledge, and acquiring knowledge. From our perspective, internal knowledge is all the knowledge that a firm has created within its boundaries, while external knowledge is the knowledge that the firm creates through customers, suppliers, competitors or partners. The former is more readily available and hence subject to greater scrutiny, while the latter is scarcer, which makes it appear more special, even unique. The internal and external knowledge processes have an impact on KIBS when compared to other service firms. Hence in this research we highlight A) confirmation of Nonaka and Takeuchi's (1995) knowledge management lifecycle model and B) internal and external knowledge acts as a tool for service innovation. These topics will be explored on the basis of a case study of a leading Indian software service provider company - Wipro. 


\section{Theoretical background: KIBS}

KIBS are "services that provide knowledge intensive inputs to the business processes of other organisations" [Miles, (2005a), p.40]. These are firms who help other firms sort out their problems which require external sources of knowledge. They simply play a role in providing information about their clients' internal and external environments, or in identifying the nature of their clients' problems. Furthermore, they provide advice, propose ways of solving those problems, or even go further to implement a solution. As Hipp (2003) argues, KIBS are more likely to produce specialised products tailored to their clients' needs.

KIBS firms play a very important role in innovation (Miles, 1999, 2005b; Hauknes, 1999; Leiponen, 2001; Gadrey and Gallouj, 2002; Kuusisto and Meyer, 2003). They are the agents of innovation across industries, and can be seen as bridging institutions in innovation systems (Kuusisto and Meyer, 2003). Many KIBS help their clients' firms with innovating (Miles, 2005b). They help distribute the knowledge and learning capacity of innovation systems as a whole (Hauknes, 1999; Miles, 2001a). Some KIBS firms are transnational, and thus can distribute their knowledge throughout the globe; yet many are small companies who are locally-based firms transferring locally specific knowledge (Miles, 2005b). KIBS has become an emerging sector for innovation research, and is potentially a rich source for empirical data from which conceptualisation in innovation in services can benefit. Based on the above information, our research hypothesis is that KIBS have to ensure that their knowledge management system allows them to capture, transfer knowledge and help in managing innovation to be competitive in the global market.

\subsection{Knowledge management}

Knowledge is an essential asset for organisations (Dixon, 1994; Pentland, 1995; Davenport and Prusak, 2000). As suggested by Rogers (1995), the innovation decision process begins with knowledge of an innovation's existence and gaining an understanding of what it does and how it functions. Therefore, managing knowledge has become vital for the success of any organisations (Radding, 1998) particularly those who seek to continuously innovate (Rogers, 1995; Quintas, 2002). The term knowledge management $(\mathrm{KM})$ itself refers to the process of critically managing knowledge to meet existing needs, to identify and exploit existing and acquired knowledge assets and to develop new opportunities [Quintas et al., (1997), p.387].

Knowledge can be classified and characterised in various ways. One of the prominent classifications is the distinction between explicit and tacit knowledge (Polanyi, 1975; Nonaka, 1994). Explicit knowledge or codified knowledge refers to the type of knowledge that is articulated into words and numbers (Becerra-Fernandez et al., 2004) and transmittable in systemic language (Nonaka, 1994). In contrast, tacit knowledge is in regard to the knowledge that people possess which has a personal quality and is difficult to codify (Hislop, 2005). Tacit knowledge is "deeply rooted in action, commitment and involvement in a specific context" [Nonaka, (1994), p.16]. Polanyi (1975) finds that tacit knowledge forms the background to interpret explicit knowledge. Explicit and tacit knowledge can be converted from and to each other. Nonaka (1994) signifies four modes of this conversion, which nicely intertwine with each KM process. These are: 
1 socialisation, a conversion process of tacit knowledge between individuals

2 combination, which combines explicit knowledge possessed by individuals

3 externalisation, the articulation of tacit into explicit knowledge through the use of metaphor (i.e., understanding and experiencing something)

4 internalisation, which represents the traditional notion of 'learning' through converting explicit into tacit knowledge.

Knowledge conversion in firms, particularly in service companies, becomes increasingly more important as it is often the core of the service business.

Figure 1 The 'engine' of knowledge creation (see online version for colours)

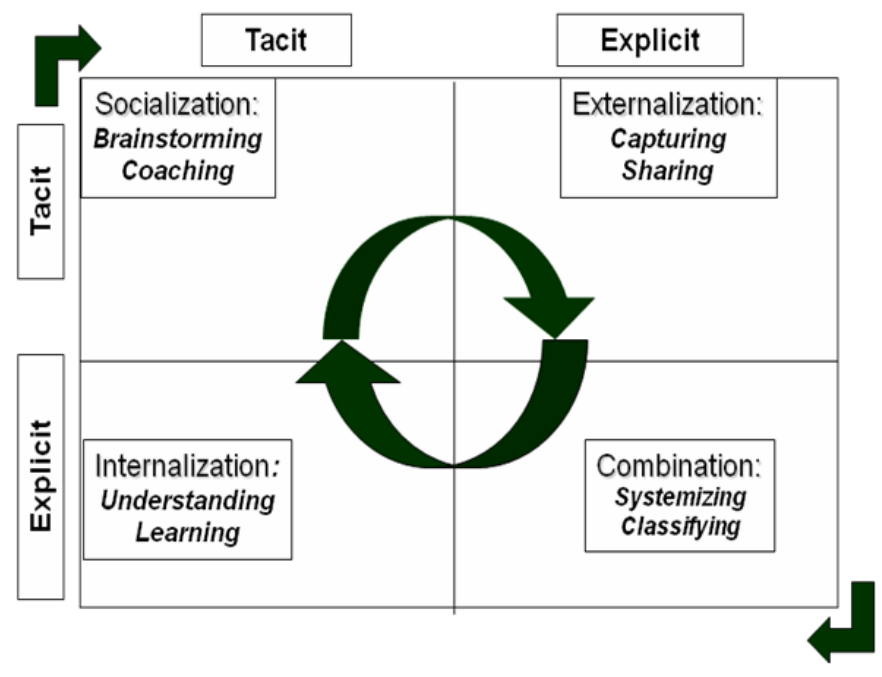

Source: Adapted from Nonaka and Takeuchi $(1995$, pp.62, 71)

The obvious challenge here is not only to deal with such conversion, but more importantly to manage the knowledge essential to firms' success in general. In order to properly manage organisational knowledge, a KM strategy needs to be formulated. Hansen et al. (1999) studied the use of IT-based knowledge management systems in knowledge intensive services. They conclude that there are two main successful uses of strategies:

1 codification, which aims to enable rapid and frequent reuse of information resources developed by the employees

2 personalisation, which targets the facilitation of communication among service workers, so as to locate and consult the appropriate expertise.

KM strategy must incorporate a KM process. Many studies identify the processes of KM in different ways (Radding, 1998; Heisig, 2001; Alavi and Leidner, 2001; Becerra-Fernandez et al., 2004). From the above literature review, we can see that there are four processes of importance to $\mathrm{KM}$ : knowledge creation, knowledge storage, knowledge distribution and knowledge application. We find that the model proposed by 
Nonaka and Takeuchi (1995) lays emphasis on internal knowledge but does not speak about external knowledge. Hence our research will test whether in Indian KIBS it is possible to confirm Nonaka and Takeuchi's (1995) model for internal knowledge but also to extend it by putting emphasis on external knowledge.

\subsection{External knowledge}

Assessment of firms' innovation performances through the role of external knowledge is identified by knowledge generation, dedicated to economic activity, into which knowledge is at the same time an output and an input (Nelson, 1982; Adams, 1990; David, 1993; Weitzman, 1996, 1998). Successful innovation has been linked to external knowledge usage. External knowledge is a result of dedicated activities which are necessary and indispensable inputs for the generation of new knowledge (Chesbrough, 2003; Chesbrough et al., 2006). Von Hippel (1988) and Gann and Salter (2000), all state the need for a stronger relationship with suppliers for innovation performance; however, their statement is basically related to project-based firms. The major sources of acquisition of external knowledge are the service sector, and suppliers of equipment, material and components (Evangelista and Sirilli, 1998).

The exploitation of external knowledge by firms can happen only through proper planning and strategy; hence the acquisition of external knowledge contributes towards firms' own competencies. Cohen and Levinthal $(1989,1990)$, state that a variety of efforts and activities by a firm is necessary for the input and generation of new technological knowledge, through dedicated activities which are, screening, identification, interaction and purchase and eventual absorption of external knowledge. Innovation is the result of a firm's creative action towards available external knowledge, hence the firms which rely on internal competencies and in-house R\&D miss opportunities which lay outside the organisation's current business drivers or they need to be combined with external knowledge and technologies to unlock their potential (Chesbrough, 2003; Von Hippel, 2005; Gassmann, 2006).

The acquisition of external knowledge relies on the firm's diverse strategies which have positive effect and challenges of management, hence innovation performance can be a consequence of how external knowledge can be acquired and differentiated (Faems et al., 2005; Van de Vrande et al., 2006). Hence we can summarise that the internal knowledge of a firm relies on the acquisition of external knowledge, and external knowledge is as important as internal knowledge.

\subsection{Service innovation}

Innovation is normally understood to be distinct from invention. While invention is the first occurrence of an idea for a new product or process, innovation is the first attempt to carry it through into practice (Schumpeter, 1934). Obviously these two are clearly linked and it is difficult to distinguish one from the other (Fagerberg, 2005) - indeed, much of the innovation literature concerns the diffusion of innovations. This literature is now very extensive, and covers a wide area of topics: the process of innovation, the economic factors determining the development and diffusion of innovations (Kay, 1993; 
Rogers, 1995), patterns of innovation and diffusion (Frambach, 1993; Rogers, 1995; Wejnert, 2002), the relationships between organisational structure and technological capacity (Burns and Stalker, 1961; Kanter, 1988), and so on. No single discipline is capable of dealing with all aspects of innovation, so much of this literature is highly cross-disciplinary.

Innovation is defined as "an idea, practice, or object that is perceived as new by an individual or other unit of adoption" [Rogers, (1995), p.12]. Rogers (1995, p.168) further introduces the term 'innovation-decision process' as the process "through which an individual (or other decision-making unit) passes from gaining initial knowledge of an innovation, to forming an attitude toward the innovation, to making a decision to adopt or reject, to implement the new idea, and to adhere to the confirmation of this decision", as innovations are needed by organisations in order to be able to compete - including services organisations. There have been numerous studies about the organisation and management of innovation in manufacturing sectors, but comparatively little about the same topic in the services sector (Miles, 2000; Tidd et al., 2001; Tidd and Hull, 2003). Services are organisations which are: typically involved in changing the state of people, artefacts, or of information and knowledge, rather than (primarily) producing material artefacts themselves (Miles, 2005a). They are usually interactive (client-intensive) whereby high levels of contact occur between service supplier and client in the service activity (Miles, 2005b). Innovation occurs as result of such interactivity, in which it often means that services' products are customised to the client's specific needs (Clayton, 2003).

Innovations in services cover many dimensions, such as service products and delivery, business and revenue models, as well as organisational structures and processes (Hauknes, 1999; Metcalfe and Miles, 2000; Miles, 2001b; Gallouj, 2002). Many service innovations are enabled by market changes as well as by developments in information technology (IT). These innovation attempts are targeted to improve quality of service production and products, to improve cost efficiency, as well as to develop new service concepts (Kuusisto and Meyer, 2003).

In general, service innovation can be categorised into non-technological and technological. The former include cases such as new financial instruments and new sales concepts (Kuusisto and Meyer, 2003), whereas the latter include cases such as the adoption of Personal Computers to support the back office tasks (Miles, 2005b). The two are very frequently combined.

Most agree that the services sectors, as well as service activity-based relationships, are essential to the knowledge economy (Miles, 2005b; Kuusisto and Meyer, 2003). Hauknes (1999) argues, however, that there has been limited research on service innovations, let alone the services' role as agents of change in the economy. Gallouj (2002) offers one possible explanation for this, i.e., that innovation in services tends to be incremental which is mostly based on 'informal activities' within the service firms themselves as well as between service suppliers and clients. More importantly, due to its incremental and informal characteristics, such developments are often difficult to capture (Kuusisto and Meyer, 2003). Service innovations occur in KIBS, due to the high interaction between KIBS and clients and also because of the rapid change in technology, which brings in better service production and products, to improve cost efficiency. 


\section{Methods}

Taking into account the nature of this study, the method is mainly qualitative. Based on a single case study we look both at the general knowledge management approach followed by the company and at a specific project implementation (BT outsourcing). The reason for choosing the case study is because it is more powerfully built for establishing theories and hypotheses based on the literature and case studies (Eisenhardt, 1989). The aim of this case study is to ascertain that our research confirms some of the findings from literature. Our case study was conducted on Wipro - a leading Indian KIBS.

We focused on service innovation and knowledge management in Indian KIBS, because they have rapid growth, deregulation, abundant resource supplies, high volume, technical advances, and attractive business opportunities which create self-reinforcing virtuous circles and therefore a platform from which the next generation of big management ideas will emerge. In India in 2011, the IT services segment was the fastest growing segment (growing by $22.7 \%$ over FY2010), and aggregating export revenues of US $\$ 33.5$ billion, accounting for $57 \%$ of total exports. Indian IT service offerings have evolved from application development and maintenance, to emerge as full service players providing testing services, infrastructure services, consulting and system integration (NASSCOM, 2011). India has been chosen as it is an emerging economy, and might pose issues specific to late comer development, which can enrich the existing theories. Therefore it is expected that showcasing Indian KIBS could shed light on the working of service firms in similar parts of the world. Within Indian KIBS we focus on the Wipro case, given that Wipro (2011b) has US\$3.4 billion. It is also one of the largest ranking top ten companies in Indian KIBS and has been awarded the Asian MAKE Award 2011, for the ninth time (Wipro, 2011b).

\section{Data collection and analysis}

Qualitative data were largely gathered through existing database and datasets on KIBS (NASSCOM, 2011) plus specific information on the company (Wipro, 2011a). Datasets are publicly available in official Wipro websites as well as the databases of industry associations, and these have been the main resource and been analysed qualitatively.

The qualitative data were analysed to provide a wider picture of the structural characteristics of the KIBS under study and KM implementation as well as innovations undertaken in the sector. This case study will offer a deeper understanding of the innovation processes in the firms and to gain insights to KM strategies and implementation and how they impact and are impacted on by innovations in KIBS.

\subsection{Case study: the Wipro technologies}

Wipro Technologies, the technology services division of Wipro Limited, is a global provider of consulting, IT services, outsourced R\&D, infrastructure outsourcing and business process services. Wipro delivers technology-driven business solutions that meet the strategic objectives of Fortune 1000 customers. With over 27 years in the IT business, Wipro is one of the world's largest outsourced R\&D services providers and one of the pioneers in the remote delivery of software services. Wipro's key differentiators include 
end-to-end services, an adaptive, knowledge-driven engagement model and an obsessive focus on quality in every aspect of service delivery.

Wipro delivers high business value to its customers through a combination of process excellence, quality frameworks, knowledge leverage and service delivery innovations. Wipro is the world's first PCMM, CMM and CMMi Level 5 certified software services company.

The company employs over 80,000 people belonging to 49 nationalities worldwide, serving over 690 customers through 52 development centres and 12 near-shore centres spread across India, Japan, China, Eastern Europe, France, Austria, Sweden, Germany, the UK, Brazil and the USA. In the fiscal year 2007 (ending March 2007), Wipro's revenues stood at approximately US\$3.4 billion. Wipro's growth is the result of a single-minded focus on customer satisfaction, quality, developing people and providing innovative value-for-money knowledge-enabled software solutions.

\subsection{Knowledge management and systems in Wipro}

Since its inception, Wipro, with its open culture, has believed in cultivating knowledge and with its business expanding, it has become all the more critical to become knowledge intensive, and implement an enterprise-wide KM system. Since there is no accepted standard framework for KM, Wipro has evolved a framework in accordance with its needs, to achieve its business vision. It has been designed to build on the existing efforts in the organisation and enhance the culture of knowledge sharing and utilisation. To build and sustain a KM system, a cultural change in the propensity to share knowledge is fundamental, which is the most difficult part of KM. An organisation should be able to induce the requisite behavioural change among people who are the contributors to and users of knowledge.

Figure 2 Wipro KM system

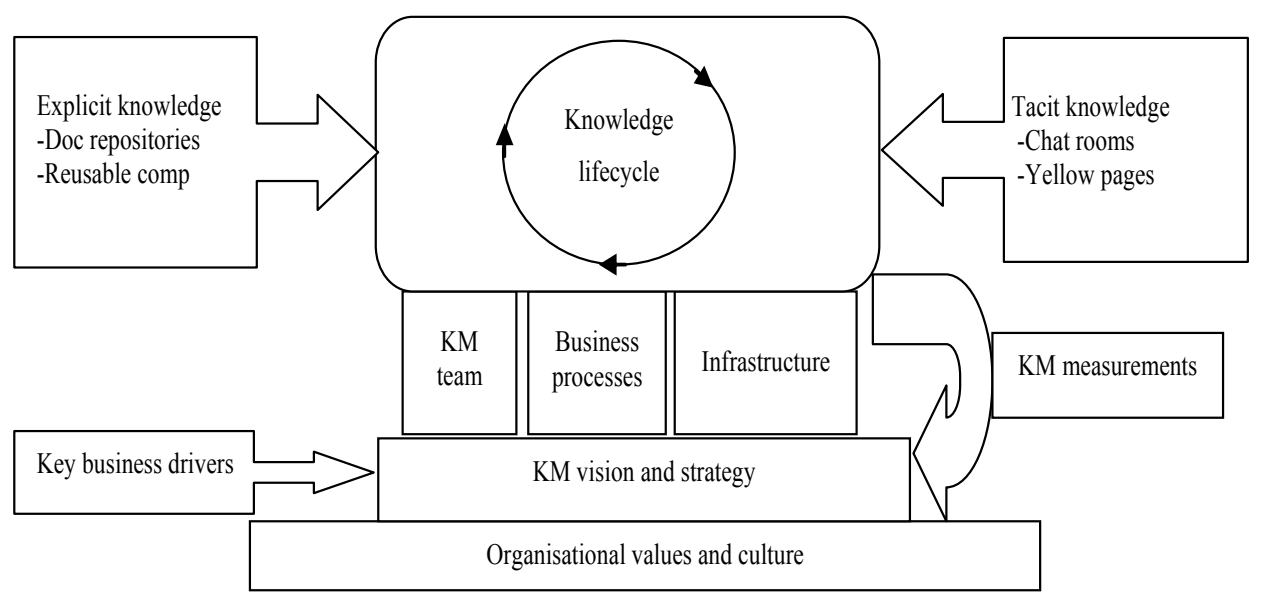

This system will capture and reuse both explicit and tacit knowledge, by identifying best practices in the field, and having a system for measurement and adequate security to protect knowledge. 


\subsection{Wipro KM framework}

Is based on three pillars

1 learning

2 knowledge enhancement, extraction and practice (KEEP)

3 competency augmentation with research excellence (CARE).

Figure 3 Wipro's KM model

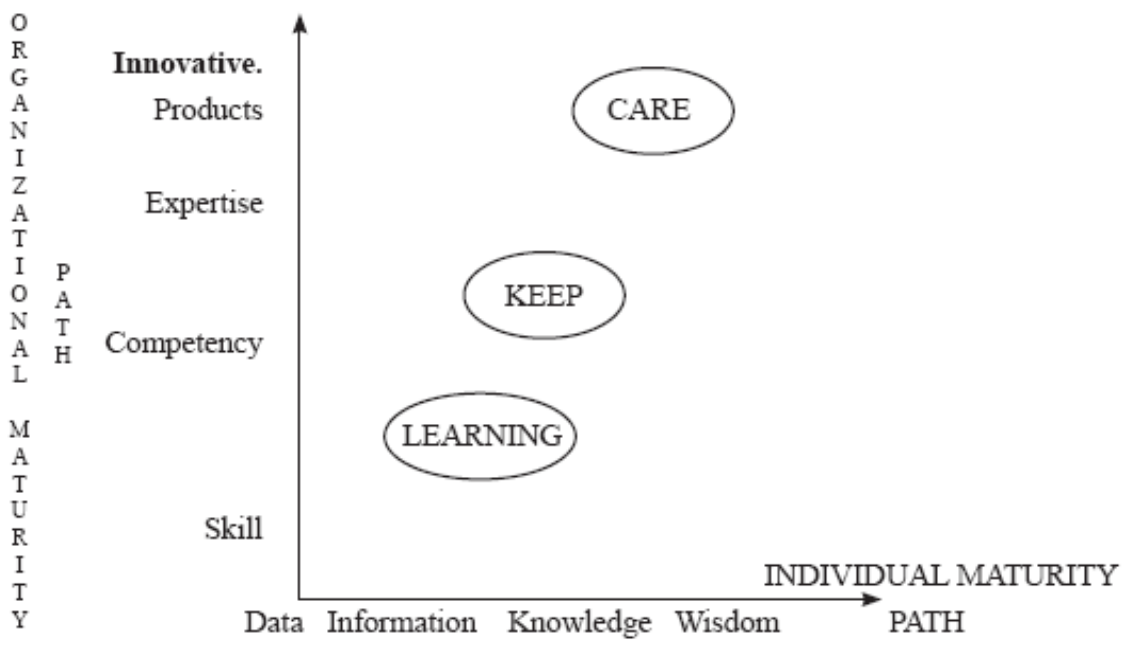

Source: Srivastava et al. (2001)

\subsection{KM business drivers for critical problems of Wipro}

Wipro identified four business drivers to overcome critical problems that it wanted to be addressed by KM

- competitive responsiveness - Wipro's ability to respond quickly to market opportunities by leveraging its collective knowledge

- collaborative work culture - working as a collaborative team, sharing best practices and avoiding reinvention or repeating mistakes

- $\quad$ shorter time to market - shortened product and project life cycles

- $\quad$ capturing tacit knowledge - minimising losses owing to attrition and mobility.

\subsection{Various ways to capture external and internal KM}

- DocKNet: Is a repository that houses documents of various types (case studies, white papers, training materials, templates, etc.) that pertain to every conceivable technology and domain that Wipro works with, and also various process documents. 
This repository is one of the most convenient ways to communicate and talk about technical matters with the rest of the technical community in Wipro.

- War rooms: These virtual workspaces are used for time-bound and task-oriented activities such as proposal preparation and framework conceptualisation. Almost all proposals that involve the participation of geographically dispersed employees go through the virtual workspace to become more efficient.

- Re-usable components: The re-usable components repository aims to eliminate the redundant development of functionalities and hence contributes towards the realisation of business benefits. The repository allows employees to share components developed to ensure shorter time-to-market periods for subsequent similar projects.

- $\quad$ Project knowledge database: The project knowledge bank provides access to historical project information captured since the time Wipro embarked on its quality journey. Using this, project managers are able to locate similar projects that have already been executed and learn from previous experience.

- Process knowledge base: Wipro's deep knowledge and expertise in quality processes and techniques have been captured and made available in a centralised knowledge base called VelociQ. This is the place to go for all the procedures, templates and guidelines related to project management. This repository also defines the project-level KM-related activities (reuse, use of best practices and expertise, and so on) supported by audits, checklists, reviews, templates and deliverables.

- Customer knowledge: In order to manage customer knowledge, the business development group and business units have restricted sites within the KNet as well as a customer relationship management application that allows globally dispersed teams to function collaboratively.

\section{Wipro's successful project implementation in enhancing services using KM: British telecom case}

In order to analyse Wipro's KM, we will look at the way they managed the BT outsourcing. BT is one of the world's largest communications services companies, based in the UK but with operations in more than 170 countries. Its main activities are providing fixed-line services, broadband, mobile phones, and TV products and services to consumers and SMEs in the UK; it also provides network-centric IT services and outsourcing to multinational enterprises worldwide as well as to other communication providers and government in the U.K. BT is the incumbent in the U.K., where it is by far the largest telecommunications provider, with divisions serving consumer, business, wholesale, and public sector markets.

BT has four main customer-facing divisions: BT retail, BT global services, BT wholesale, and open reach. The two other main divisions, BT innovate and design and BT operate, develop and run the offerings (and the associated underlying infrastructure) on behalf of the four customer-facing divisions.

BT innovate and design develops, designs, and delivers the processes, networks, and platforms on behalf of the customer-facing lines of business. BT operate manages BT's 
IT and network infrastructure platforms, including $21 \mathrm{CN}$, the next-generation internet-based voice and data network. BT operate's strategy and service introduction (SSI) function acts as a single focus point, undertaking all activities of a new release of a BT offering, providing assurance to BT's customer-facing businesses about the new and/or changed services.

\subsection{Challenges}

In late 2008, BT was using a mix of internal resources and third parties, mostly individual contractors, all of which were based onshore. The fact that work was performed entirely onshore and by a relatively large number of external contractors that were paid on a time-and-materials basis meant that the process was both expensive and difficult to manage in an end-to-end manner, making it hard to drive improvements in quality, efficiency, and cost. BT decided that it needed to drive significant reductions in the cost of its release-service introduction, testing, and deployment activities. BT wanted to drive significant increases in the efficiency and quality of these activities, so that the end-user experience - both internal and external - was improved. BT also wanted to improve its managers' understanding and control of these activities, by improving process governance and transparency and by creating better key performance indicators (KPIs) and service level agreements (SLAs) (Wipro, 2011a).

\subsection{Strategy and solution}

BT short listed five suppliers with significant offshore-based IT services capabilities, and chose Wipro, signing two parallel deals for release management and deployment management in May 2009. Wipro is one of the leading offshore vendors operating in Europe, specialising in technology and business consulting, outsourcing, and product engineering services.

Although the quality of all the short listed vendors was strong, BT felt that Wipro had the edge in terms of responsiveness and flexibility during the tendering, with the India-based company quickly and iteratively adapting its draft proposals and its commercial terms as the dialogue between BT and its potential vendors developed.

BT and Wipro agreed a three-phase approach to taking the release and deployment services offshore and transforming them. The key principles were standardisation of processes and services, establishment of a single catalogue of service, SLA-driven delivery with meaningful KPIs and full transparency of performance, and "cross leveraging of learning" by Wipro leading to continual service improvement - in other words, Wipro would apply best practices and lessons learned from other industries and clients to BT's service delivery. BT and Wipro created two types of team involved in the release and deployment management processes: 'core' teams with responsibility for business-critical activities and 'flex' teams with responsibility for less critical activities. The core teams supervise the flex teams and allocate work to them.

During the transition phase, Wipro had a two-month window to acquire knowledge of the transferred services and of BT's processes, culture, and key people before taking the transferred work fully offshore. During this phase, Wipro had to work closely with BT people spread across multiple lines of business. To speed up the process and minimise risk, Wipro and BT differentiated between the transition of business-critical work and the transition of less critical work. 
In this project, BT was most impressed by Wipro's high level of collaboration, both in terms of the way it managed operational delivery but also in the way it agreed commercial terms. For example, Wipro was happy to suggest tougher KPIs during annual review sessions, and indeed did so unprompted, and the India-based supplier proactively rewrote feedback questions for internal customers to make the questions more probing and thus deliver greater insight and value.

Wipro ensured the smoothness of this transition in part by ensuring that it brought many of its best offshore people onshore to work alongside BT for a period, getting to know the processes, people, and culture of the client. On occasions when the 'fit' between BT and Wipro personnel was not right, Wipro acted quickly by swapping its people with alternative personnel. This helped to ensure that the Wipro team serving BT had very low levels of people churn.

Wipro proactively took knowledge and insights gained from other engagements and applied this when problem-solving for BT, and also the way it deployed high-level staff and/or relatively large teams to fix problems quickly and at root cause. Wipro was good at bringing expertise to bear on the problem.

In fact David Butcher, the managing directorof Service Introduction at BT Operate stated "They have been very keen to showcase their wider industry knowledge, and on occasions they got their top people in to help us. We find that they're willing to take lessons learned from one area and apply them to another" (Wipro, 2011a).

\section{Summary of achieved results by Wipro}

BT judges the project to have been a clear success; the company was going through the initial stage of re-tendering the initial deal (Wipro, 2011a). By consolidating external suppliers and taking work offshore into 'factories' benefiting from economies of scale, BT has cut the delivery costs of the release-service introduction and deployment management activities significantly, i.e., by around $60 \%$. Savings were not simply from labour arbitrage - much of the cost savings came from the better management of processes.

Process quality has improved significantly as a result of the project. The off-shored processes have moved from being bespoke to being standardised, bringing savings in cost and improvements in manageability and quality. Wipro has taken the processes under its management from process maturity Level 2 to Level 4, while BT now has a more formal go/no-go decision process for releases. BT has reduced the number of customer-impacting faults, introduced during the service introduction cycle, by an estimated $80 \%-85 \%$. Cycle deployment times have reduced significantly, with $68 \%$ and $69 \%$ reduction in cycle times respectively for low-complexity and moderate-complexity deployment projects. BT now has stronger governance and greater transparency in its release management and deployment cycle.

\subsection{The processes and importance of external and internal knowledge at Wipro}

From the above case study, we can say Wipro needed a way to create, store, distribute and apply its internal and external knowledge gained by its employees and also through various project implementations. Hence it built Knowledge net (KNet) to provide a 
unified repository of external and internal knowledge. Wipro's aim to have a knowledge management repository was to help employees find the right people with the right knowledge and domain expertise. KNet has helped reduce time-to-market, increased efficiency, and improved collaboration among employees.

As number of users kept on increasing, KNet was able to handle the security requirements arising out of increased access over the internet. The solution has added a new level of innovation to the way in which the company's employees share and access information. Scientific and technological knowledge is required for innovative activities in order to have competencies, and external sources such as knowledge and experience (Teece, 1986). As per Strambach (2001), there are three elements for KM, which are: acquiring tacit and codified knowledge, diffusion of knowledge, and combining external and internal knowledge.

We have seen in the literature that combining knowledge refers to the process where external knowledge is acquired through interaction with various segments and is then combined with existing knowledge and when additional knowledge is required new knowledge is generated (Strambach, 2001). In their research, Van Den Bosch et al. (1999), found that new knowledge is created by service industries when their knowledge, coming from outside, is combined with current knowledge. It is critical for successful innovations (Kline and Rosenberg, 1986; Rothwell, 1992). In this paper we have stated our definition of the importance of combining external and internal knowledge for innovation which will create new knowledge. KIBS firms are more reliant nowadays on projects in managing complex systems and products. Project processes are unique and temporary (Gann, 1998; Brusoni et al., 1998), and often present some features which are not repeated systematically. As per March and Stock (2003), previous experience in handling projects can help a firm develop new or improve existing processes for product development.

Nonaka et al. (2001) state that interaction of individuals in an organisation helps in creating knowledge and in order to innovate it is essential that this has the involvement employees (Clark and Fujimoto, 1991; Cooper, 1999). Even though as an individual the contribution is minimal, nonetheless the sum of all makes a huge impact (Tidd et al., 1997). Grant (1996) had earlier mentioned that to have competitive advantage, firms need to have strong knowledge of both external and internal knowledge rather than just having knowledge. So we can say that combining internal and external knowledge is very important for innovation (Leonard-Barton, 1992; Moorman and Miner, 1997).

As seen in Wipro's usefulness of knowledge management repository for combining external and internal knowledge, and for successful implementation of the project with BT, the difference they made towards BT's services extended to their customers. The evidences from the case study confirms our hypothesis that: Nonaka and Takeuchi's (1995) KM life cycle model has to be extended to include external knowledge, and that external and internal knowledge act as a tool for service innovation.

\section{Conclusions and limitations}

On the basis of the literature reviews as well as the case study, we confirm the relevance of Nonaka and Takeuchi's (1995) 'knowledge management life cycle model' in Wipro's KM system, regarding its internal Knowledge. However, the existing literature on service innovation and KM has not fully investigated the importance of external knowledge on 
service innovation in KIBS firms. Hence, in this study, we have explored the effect of external knowledge for innovation in KIBS. The ability of organisations to create, transfer, assemble, integrate and leverage knowledge is fundamental to achieving innovation and thus gaining competitive advantage. Creating new knowledge, however, often involves acquiring internal and external knowledge. A balanced approach is needed towards knowledge management strategy, and the understanding of knowledge to identify, refine, and solve market-based problems through creative decision-making, which in turn results in the development of new knowledge from both internal and external sources, leading to service innovation. Hence it is fundamental for KIBS firms to have both internal and external knowledge enabling them to have knowledge intensive development.

In the case study, the interaction of Wipro employees with BT enabled them to handle complex issues and helped in identifying external knowledge through the client. Miles (2005b) stated that; service innovation is usually interactive (client-intensive) whereby a high level of contact is required between service supplier and client in the service activity. Von Hippel (1988) and Gann and Salter (2000), have stated the importance of the usage of external knowledge for successful innovation, by having a close relationship with suppliers on innovation performance; this relationship is particularly important in project-based firms.

The results complement the existing theory on service innovation, and knowledge management in KIBS, as well as bringing in managerial implications by providing insights for firms to innovate better. Since our research is based on qualitative analysis and also through a single case study we wish to enhance it by conducting multiple case studies, large scale surveys in firms related to KIBS in India and to test our proposition.

\section{References}

Adams, J.D. (1990) 'Fundamental stocks of knowledge and productivity growth', Journal of Political Economy, Vol. 98, No. 4, pp.673-702.

Ahuja, G. and Katila, R. (2001) 'Technological acquisitions and the innovation performance of acquiring firms: a longitudinal study', Strategic Management Journal, Vol. 22, No. 3, pp.197-220.

Alavi, M. and Leidner, D.E. (2001) 'Knowledge management and knowledge management systems: conceptual foundations and research issues', MIS Quarterly, Vol. 25, No. 1, pp.107-136.

Becerra-Fernandez, I. (2004) Knowledge Management: Challenges, Solutions, and Technologies, Pearson Education, Inc., Upper Saddle River.

Brusoni, S., Precipe, A. and Salter, A. (1998) Mapping and Measuring Innovation in Project-Based Firms, CoPS Working Paper, CENTRIM/RSPRU, Brighton.

Burns, T. and Stalker, G. (1961) The Management of Innovation, Tavistock, London.

Chesbrough, H. (2003) Open Innovation, the New Imperative for Creating and Profiting from Technology, Harvard Business School Press, Boston.

Chesbrough, H., Vanhaverbeke, W. and West, J. (2006) Open Innovation: Researching a New Paradigm, Oxford University Press, Oxford.

Child, J., Faulkner, D. and Pitkethly, R. (2001) The Management of International Acquisitions, Oxford University Press, Oxford.

Clark, K.B. and Fujimoto, T. (1991) Product Development Performance, Harvard Business School Press, Boston. 
Clayton, T. (2003) 'Service innovation: aiming to win', in Service Innovation: Organisational Responses to Technological Opportunities \& Market Imperatives, pp.113-133, Imperial College Press, London.

Cohen, W.M. and Levinthal D.A. (1990) 'Absorptive capacity: a new perspective on learning and innovation', Administrative Science Quarterly, Vol. 35, No. 1, pp.128-152.

Cohen, W.M. and Levinthal, D.A. (1989) 'Innovation and learning: the two faces of R\&D', Economic Journal, Vol. 99, No. 397, pp.569-596.

Cooper, R.G. (1999) 'From experience: the invisible success factors in product innovation', Journal of Product Innovation Management, Vol. 16, No. 2, pp.115-133.

Davenport, T.H. and Prusak, L. (2000) Working Knowledge: How Organisations Manage What They Know, Harvard Business School Press, Boston, MA.

David, P.A. (1993) 'Knowledge property and the system dynamics of technological change', Proceedings of the World Bank Annual Conference on Development Economics, The World Bank, Washington.

Den Hertog, P. (2000) 'Knowledge-intensive business services as co-producers of innovation', International Journal of Innovation Management, Vol. 4, No. 4, pp.491-528.

Dixon, N.M. (1994) The Organisational Learning Cycle: How We Can Learn Collectively, McGraw Hill, London.

Eisenhardt, K.M. (1989) 'Making fast strategic decisions in high velocity environments', Academy of Management Journal, Vol. 32, No. 3, pp.543-576.

Eurostat (1995) Report of the Eurostat Pilot Project to Investigate the possibilities to Measure Innovation in the Service Sectors, Eurostat, Luxemburg.

Evangelista, R. and Sirilli, G. (1998) 'Innovation in the service sector: results from the Italian statistical survey', Technological Forecasting and Social Change, Vol. 58, No. 3, pp.251-269.

Faems, D., Looy, B.V. and Debackere, K. (2005) 'Interorganizational collaboration and innovation: toward a portfolio approach', Journal of Product Innovation Management, Vol. 22, No. 3, pp.238-250.

Fagerberg, J. (2005) 'Innovation: a guide to the literature', in Fagerberg, J., Mowery, D. and Nelson, R. (Eds.): The Oxford Handbook of Innovation, Oxford University Press, New York.

Frambach, R.T. (1993) 'An integrated model of organizational adoption and diffusion of innovations', European Journal of Marketing, Vol. 27, No. 5, pp.22-41.

Gadrey, J. and Gallouj, F. (2002) Productivity, Innovation and Knowledge in Services, Elgar, Cheltenham.

Gallouj, F. (2002) 'Innovation in services and the attendant old and new myths', Journal of Socio-Economics, Vol. 31, pp.137-154.

Gallouj, F. (2002) Innovation in the Service Economy -The New Wealth of Nations, Edgar Elgar, Cheltenham, UK.

Gann, D.M. (1998) 'New manufacturing for the 21st century', AEGIS Conference Generating New Wealth for Australia, Sydney, 30 March.

Gann, D.M. and Salter, A.J. (2000) 'Innovation in project-based, service-enhanced firms: the construction of complex products and systems', Research Policy, Vol. 29, Nos. 7-8, pp.955-972.

Gassmann, O. (2006) 'Opening up the innovation process: towards an agenda', R\&D Management, Vol. 36, No. 3, pp.223-228.

Grant, R.M. (1996) 'Prospering in dynamically-competitive environments: organizational capability as knowledge integration', Organization Science, Vol. 7, No. 4, pp.375-387.

Hansen, M., Nohria, N. and Tierney, T. (1999) 'What's your strategy for managing knowledge?', Harvard Business Review, Vol. 77, No. 2, pp.106-116.

Haspeslagh, P.C. and Jemison, D.B. (1991) Managing Acquisitions: Creating Value through Corporate Renewal, The Free Press, New York. 
Hauknes, J. (1998) Services in Innovation--Innovation in Services, Research Report, STEP Group, Oslo, Norway.

Hauknes, J. (1999) Services in Innovation - Innovation in Services, Report for the OECD Business and Industry Policy Forum, Paris, France.

Heisig, P. (2001) 'Business process oriented knowledge management, in knowledge management: best practices in Europe', in K. Mertins, P. Heisig and J. Vorbeck (Eds.), pp.13-36, Springer, Berlin.

Hipp, C. (2003) 'Effects of innovation in standardised, customized and bespoke services: evidence from Germany', in J. Tidd and F.M. Hull (Eds.): Service Innovation: Organisational Responses to Technological Opportunities \& Market Imperatives, pp.175-210, Imperial College Press, London.

Hislop, D. (2005) Knowledge Management in Organisations: A Critical Introduction, Oxford University Press, Oxford.

Kanter, R. (1988) 'When a thousand flowers bloom: structural, collective and social conditions for innovation in organisations', Research in Organizational Behaviour, Vol. 10, pp.169-211.

Kay, J. (1993) 'The structure of strategy', Business Strategy Review, Vol. 4, No. 2, pp.17-37.

Kelley, T. and Littman, J. (2001) The Art of Innovation: Lessons in Creativity from IDEO, America's Leading Design Firm, HarperCollins, Great Britain.

Kline, S.J. and Rosenberg, N. (1986) 'An overview of innovation', in: Landau, R. and Rosenberg, N. (Eds.): The Positive Sum Strategy: Harnessing Technology for Economic Growth, the National Academy Press, Washington DC.

Kuusisto, J. and Meyer, M. (2003) 'Insights in to services and innovation in the knowledge intensive economy', Technology Review, 134/2003, Tekes, Helsinki.

Leiponen, A. (2001) Knowledge Services in the Innovation System, ETLA, Helsinki.

Leonard-Barton, D. (1992) 'Core capabilities and core rigidities: a paradox in managing new product development', Strategic Management Journal, Summer, Vol. 13, No. S1, pp.111-125.

March, S.J., and Stock, G.N. (2003) 'Building dynamic capabilities in new product development through intertemporal integration', Journal of Product Innovation Management, Vol. 20, No. 2, pp.136-148.

Martin, C.R. and Horne, D.A. (1993) 'Service innovation: successful versus unsuccessful firms', International Journal of Service Industry Management, Vol. 4, No. 1, pp.48-64.

Metcalfe, S. and Miles, I. (2000) Innovation Systems in the Service Economy: Measurement and Case Study Analysis, Kluwer Academic Publishing, Massachusetts, USA.

Miles, I. (1999) 'Services in national innovation systems: from traditional services to knowledge intensive business services', in G. Schienstock and O. Kuusi (Eds.): Transformation Towards a Learning Economy: the Challenge to the Finnish Innovation System, SITRA (Finnish National Fund for R\&D) Helsinki.

Miles, I. (2000) 'Environmental services: sustaining knowledge', in B. Andersen, J. Howells, R. Hull, I. Miles and J. Roberts (Eds.): in Knowledge and Innovation in the New Service Economy, Elgar, Aldershot.

Miles, I. (2001a) 'Knowledge intensive business services and the new economy, CRIC and PREST', University of Manchester, at a Seminar Presentation at the Evolutionary Economics Unit, Max Planck Institute for Research into Economic Systems, Jena, Germany.

Miles, I. (2001b) 'Knowledge-intensive business services revisited', Nijmegen Lectures on Innovation Management, Maklu, Antwerpen-Apeldoorn.

Miles, I. (2005a) 'Knowledge intensive business services: prospects and policies', Foresight, Vol. 7, No. 6, pp.39-63.

Miles, I. (2005b) 'Innovation in services', in J. Fagerberg, D.C. Mowery and R.R. Nelson (Eds.): The Oxford Handbook of Innovation, pp.433-458, Oxford University Press Inc., New York. 
Miles, I., Kastrinos, N., Flanagan, K., Bilderbeek, R., Hertog, P., Huntink, W. and Bouman, M. (1995) Knowledge-Intensive Business Services: Users, Carriers, and Source of Innovation, EIMS Publication No. 15, Innovation Programme, Directorate General for Telecommunications, Information Market and Exploitation of Research, Commission of the European Communities, Luxembourg.

Moorman, C. and Miner, A.S. (1997) 'The impact of organizational memory on new product development performance and creativity', Journal of Marketing Research, Vol. 34, No. 1, pp.91-106.

Muller, E. and Zenker, A. (2001) 'Business services as actors of knowledge transformation: the role of KIBS in regional and national innovation systems', Research Policy, Vol. 30, No. 9, pp.1501-1516.

NASSCOM (2011) Research report [online] http://www.nasscom.in/sites/default/files/researchreports/Exec\%20Summary_0.pdf (accessed 26 May 2012).

Nelson, R.R. (1982) 'The role of knowledge in R\&D efficiency', Quarterly Journal of Economics, Vol. 97, No. 3, pp.453-470.

Nonaka, I. (1994) 'A dynamic theory of organizational knowledge creation', Organization Science, Vol. 5, No. 1, pp.14-37.

Nonaka, I. and Takeuchi, H. (1995) The Knowledge-creating Company, Oxford University Press, New York.

Nonaka, I., Konno, N. and Toyama, R. (2001) 'Emergence of "Ba": a conceptual framework for the continuous and self-transcending process of knowledge creation', in Nonaka, I. and Nishiguchi, T. (Eds.): Knowledge Emergence: Social, Technical, and Evolutionary Dimensions of Knowledge Creation, Oxford University Press, New York.

Pentland, B.T. (1995) 'Information systems and organisational learning: the social epistemology of organisational knowledge systems', Accounting, Management \& Information Technology, Vol. 5, No. 1, pp.1-21.

Polanyi, M. (1975) 'Personal knowledge', in M. Polanyi and H. Porsch (Eds.): Meaning, pp.22-45, University of Chicago Press, Chicago, Illinois.

Quintas, P. (2002) 'Managing Knowledge in a New Century', in S. Little, P. Quintas and T. Ray (Eds.): Managing Knowledge: An Essential Reader, pp.1-14, Sage Publications, London.

Quintas, P., Lefrere, P. and Jones, G. (1997) 'Knowledge management: a strategic agenda', Long Range Planning, Vol. 39, No. 3, pp.385-391.

Radding, A. (1998) Knowledge Management: Succeeding in the Information based Global Economy, Computer Technology Research Corp., Charleston, USA.

Rogers, E.M. (1995) Diffusion of Innovations, 5th ed., Free Press, New York.

Rothwell, R. (1992) 'Successful industrial innovation: critical factors for the 1990s', R\&D Management, Vol. 22, No. 3, pp.221-239.

Schumpeter, J. (1934) The Theory of Economic Development, Harvard University Press, Cambridge, MA.

Srivastava, A., Rajendhiran, N., Prasanna, N. and Prasad, S. (2001) 'KM in Wipro infotech - a case review', Management Review, Vol. 13, No. 4, pp.111-116.

Strambach, S. (2001) Innovation processes and the role of knowledge-intensive business services', in Koschatzky, K., Kulicke, M. and Zenker, A. (Eds.): Innovation Networks - Concepts and Challenges in the European Perspective, pp.53-68, Heidelberg: Physica.

Teece, D.J. (1986) 'Profiting from technological innovation: Implications for integration, collaboration, licensing and public policy', Research Policy, Vol. 15, No. 6, pp.286-305.

Tidd, J. and Hull, F.M. (2003) 'Managing service innovation: variations of best practice', in J. Tidd and F.M. Hull (Eds.): Service Innovation: Organisational Responses to Technological Opportunities \& Market Imperatives, pp.3-34, Imperial College Press, London. 
Tidd, J., Bessant, J. and Pavitt, K. (1997) Managing Innovation: Integrating Technological, Market, and Organizational Change, Wiley, Chichester.

Tidd, J., Bessant, J. and Pavitt, K. (2001) Managing Innovation: Integrating Technological, Market and Organisational Change, 2nd ed., John Wiley, Chichester.

Van de Vrande, V., Lemmens, C. and Vanhaverbeke, W. (2006) 'Choosing governance modes for external technology sourcing', R\&D Management, Vol. 36, No. 3, pp.347-363.

Van Den Bosch, F.A., Volberka, H.W. and Boer, M. (1999) 'Co evolution of firm absorptive capacity and knowledge environment: organizational forms and combinative capabilities', Organization Science, Vol. 10, No. 3, pp.551-568.

Von Hippel, E. (1988) The Sources of Innovation, Oxford University Press, Oxford.

Von Hippel, E. (2005) Democratizing Innovation, The MIT Press, Cambridge.

Weitzman, M.L, (1998) 'Recombinant growth', Quarterly Journal of Economics, Vol. 113, No. 2, pp.331-360.

Weitzman, M.L. (1996) 'Hybridizing growth theory', American Economic Review, Vol. 86, No. 2, pp.207-212.

Wejnert, B. (2002) 'Integrating models of diffusion of innovations: a conceptual framework', Annual Review of Sociology, Vol. 28, No. 1, pp.236-297.

Wipro (2011a) BT-Wipro Case Study, IDC [online]

http://www.wipro.com/Documents/IDC_BT-Wipro_Case_Study_\%282011\%29.pdf (accessed 26 May 2012).

Wipro (2011b) Newsroom [online]

http://www.wipro.com/newsroom/Pages/press-releases-details.aspx?PRID=37 (accessed 26 May 2012). 